\title{
Female Labour Force Participation and Economic Development in Southeast Asia
}

\author{
Siti Amalia \#1, Rizky Yudaruddin" ${ }^{\# 2}$ \\ \# Faculty of Economics and Business, Mulawarman University \\ Samarinda, Indonesia \\ ${ }^{1}$ sitiamaliaefeb.unmul.ac.id \\ 2rizky.yudaruddinefeb.unmul.ac.id
}

\begin{abstract}
The magnitude of women's role in the economy becomes a serious concern of the government in the era of the ASEAN Economic Community (MEA). This study focuses on Female Labor Force Participation and Economic Development in Southeast Asia. Using panel data period 1993-2013, this study aims to prove the U-shaped Female Labor Force Participation and Economic Development. The results prove that there is a $U$ shaped relationship between Female Labor Force Participation and Economic Development in Southeast Asia.
\end{abstract}

Keywords - component; Female Labour Force Participation, Economic Development and Southeast Asia

\section{INTRODUCTION}

In 2014, International Labor Organization (ILO) reported that in some developing countries, women still face obstacles in entering the labor market. Overall, the labor force participation rate of women reached 50.3 percent, which means that half of all working age women are working or looking for work [1]. Based on this situation, we need a positive perspective for improving the role of women. The goal is to accelerate economic growth and job opportunities that can help counteract the impact of demographic shifts and unproductive populations. Thus, a strong policy framework is needed to integrate women in the economy and reduce barriers for women to be productive.

Indeed, unknowingly, women contribute greatly to economic well-being through unpaid work, child care and household chores, which are often fixed, invisible, and yet found in Gros Domestic Product (GDP). Women's ability to participate in the labor market is limited by higher allocations over time to unpaid work. On average, women spend twice as much time on housework than men and four times more for children. This condition provides free space for male household members to participate in the formal labor force. In developing countries including Association of Southeast Asian Nations
(ASEAN), women spend about $21 / 2$ hours more than men on unpaid work (including nursing jobs) every day, regardless of the employment status of their husbands [2].

In the case of Indonesia, ahead of the ASEAN Economic Community (MEA) in 2015, the government declared the level of productivity and labor education in Indonesia is still very low compared to Singapore, Malaysia, Thailand and the Philippines. This condition can illustrate the readiness of Indonesian workers in ASEAN. Therefore, the Indonesian government will increase labor productivity by increasing the participation of women in employment. For 20 years, the participation rate of Indonesian women is not much moving only $50.3 \%$ meaning that every 100 women aged 15 years and over there are about 50 people who have the potential to enter the world of work. While Thailand $45.4 \%$, Philippines $41.8 \%$. The contribution of women was more in the sector with low added value. Yet according to the Indonesian Chamber of Commerce and Industry (Kadin), Indonesia estimates the number of workers in ASEAN will reach about 320 million in 2015. It is estimated that the increase in employment occurs in the Philippines and Cambodia, whose economic conditions are still weak. While Thailand, Singapore, Malaysia and Brunei are expected to experience labor shortages after 2015. This is because their economies are growing faster than the increase in population. As a result, with the existence of the economic community of ASEAN (AEC), it will open the business and employment opportunities for workers in Indonesia.

This study aims to examine the impact of changes in economic structure on Female Labor Force Participation in the ASEAN Region for 21 
years from 1993 to 2013. The participation rate of female labor force follows a "U" shaped pattern. The first phase of employment development in the traditional sector will decreases faster than the increase in employment in the modern sector thereby reducing employment and increasing unemployment, especially among women. But at the same time the process of development also increases the family's income, thereby reducing the economic pressures that previously forced women to work. Both of these things cause women to tend to get out of economically active and cause the labor force participation rate of women to decline.

Increased economic activity will increase women's chances of having easier and better access to employment so as to encourage women to become economically active to increase women's participation in productive activities. However, the rise of female labor force participation in ASEAN region still faces various obstacles such as cultural factors, religion, family responsibilities and government policies though the government has provided various spaces for women in increasing their participation in the world of work through the improvement of education for women. This is because the participation rate of the female labor force can be an indicator of the extent to which the success of the government in providing space for the participation of gender equality and employment opportunities for women especially education and employment in the formal sector

\section{LITERATURE REVIEW}

Female labor force participation is influenced by various factors such as economic, social and cultural. Economic factors became one of the factors that many researchers studied in particular related to changes in the economic structure of a country. [3] and [4] which provide theoretical direction to the role of female labor force participation in economic development. The longterm relationship between the female labor force participation rate and economic development shows the U-shape. The findings of the previous studies that are U-shape relationship with economic development [4], [5], [6], [7], [8] [9], [10] and [11].

Changes in the economic structure occurring in the development process affect the female labor force participation that follows the U-shaped pattern. $U$ shape means that female labor force participation in early development will decrease due to the effect of industrialization. Although it will again increase in the relative amount of the service sector of the type of work that is administrative. This is because during industrialization, an increase in family income that lowers economic levels causes women to work. However, when the development reaches peak condition, what happens is the opposite of the woman is pushed to re-enter the work force due to the increase of education, wages and the desire to enjoy the results of development. Increased economic activity will expand women's opportunities to have easier and better access to jobs. As a result women become economically active and increase female labor force participation.

This research also involves control variables such as Urban Population, Unemployment and Fertility. Urban areas open up opportunities for greater employment opportunities compared to rural areas. The higher the proportion of people living in urban areas, the higher the female labor force participation. This is because an increase in economic growth will increase the availability of employment so that it will attract high levels of labor force participation including women. Results of previous studies [6], [11] [12] [13] and [14], found significant negative effects urban population on female labor force participation. While the study [15] showed a significant positive effect on female labor force participation.

The impact of unemployment on female labor force participation is negative. This means that the increasing number of unemployed job opportunities decreased so that the participation rate of female labor force will increase. So the increase in unemployment has a tendency to lower the possibility of women entering the labor market. Results [6], [11] and [16] found that unemployment had a significant negative effect on the participation rate of the female labor force.

The relationship between fertility rates as measured by the number of children born by women is negative to the female labor force participation rate. If the number of women giving birth increases, it will decrease the female labor force participation rate due to the limited time for women to access the labor market and participate in improving family 
welfare. Results of the study [12], [7], [17], [11], [15] and [18] fertility had significant negative female labor force participation. While [14] found a different thing that is significant positive.

\section{METHOD}

The analysis of the relationship of female labor force participation and economic development is based on the research by [4] and [11] which is then formed in a model as follows:

FLPR $_{\mathrm{i}, \mathrm{t}}=\beta_{1}+\beta_{2}$ LGDP $_{\text {all i,t }}+\beta_{3}$ LGDP $^{2}{ }_{\mathrm{i}, \mathrm{t}}+\beta_{4} \mathrm{URBAN}_{\mathrm{i}, \mathrm{t}}+$ $\beta_{5}$ UNEMPLOY $_{\mathrm{i}, \mathrm{t}}+\beta_{6}$ FERTIY $_{\mathrm{i}, \mathrm{t}}$

where Labor force participation rate (FLPR) is the proportion of the population ages 15 and older that is economically active: all people who supply labor for the production of goods and services during a specified period. Gross Domestic Product per capita (GDP) is gross domestic product divided by midyear Population. Urban population (URBAN) refers to people living in urban areas as defined by national statistical office. Unemployment (UNEMPLOY) refers to the share of the labor force that is without work but available for and seeking employment. Total fertility rate (FERTIY) represents the number of children that would be born to a woman if she were to live to the end of her childbearing years and bear children in accordance with age-specific fertility rates of the specified year.

Pooled time series cross-section data are employed for 10 countries for the period 19932013. Southeast Asian country consists of Indonesia, Singapore, Malaysia, Thailand, Myanmar, Philippines, Brunei Darussalam, Vietnam, Lao PDR and Cambodia. The data used is sourced from Word Bank. The analysis tool used is panel data regression.

\section{RESUlT AND DisCUSSION}

Table 1 provides the descriptive statistics for the variables used in the study. The average FLPR for all Countries in Southeast Asian is 60,49 percent ( standard deviation $=12.41$ ). Indonesia is the country with the lowest FLPR compared to Southeast Asian Countries and Lao PDR is the country with the highest FLPR compared to Southeast Asian countries.. Average GDP, URBAN, FERTY and UNEMPLOY for all Countries are 7.55, 48.04, 2.64 and 3.68, respectively.

TABLE I.

DESCRIPTIVE STATISTICS OF VARIABLES

\begin{tabular}{|c|c|c|c|c|c|c|c|c|c|c|}
\hline \multirow{2}{*}{ Countries } & \multicolumn{2}{|c|}{ FLPR } & \multicolumn{2}{|c|}{ GDP } & \multicolumn{2}{|c|}{ URBAN } & \multicolumn{2}{|c|}{ FERTY } & \multicolumn{2}{|c|}{ UNEMPLOY } \\
\hline & Mean & Stdv. & Mean & Stdv. & Mean & Stdv. & Mean & Stdv. & Mean & Stdv. \\
\hline Brunei Darussalam & 53.49 & 2.16 & 9.72 & 1.23 & 72.41 & 2.84 & 2.37 & 0.37 & 3.74 & 0.32 \\
\hline Cambodia & 76.98 & 1.47 & 5.91 & 0.79 & 18.77 & 1.06 & 3.60 & 0.69 & 1.28 & 0.81 \\
\hline Indonesia & 50.47 & 0.73 & 6.99 & 0.96 & 43.74 & 5.76 & 2.53 & 0.12 & 7.13 & 2.16 \\
\hline Lao PDR & 78.11 & 1.38 & 6.04 & 0.84 & 25.62 & 6.44 & 4.06 & 0.87 & 1.81 & 0.43 \\
\hline Malaysia & 43.74 & 0.87 & 8.35 & 1.05 & 64.67 & 6.54 & 2.57 & 0.55 & 3.30 & 0.39 \\
\hline Philippines & 49.84 & 1.25 & 6.99 & 0.88 & 48.11 & 0.85 & 3.59 & 0.36 & 8.71 & 1.68 \\
\hline Singapore & 53.37 & 3.20 & 10.00 & 1.24 & 100.00 & 0.00 & 1.33 & 0.37 & 3.31 & 0.92 \\
\hline Thailand & 65.46 & 0.96 & 7.75 & 0.97 & 32.64 & 3.76 & 1.63 & 0.17 & 1.51 & 0.74 \\
\hline Vietnam & 72.92 & 0.52 & 6.21 & 0.92 & 26.39 & 3.45 & 2.09 & 0.38 & 2.33 & 0.31 \\
\hline All Countries & 60.49 & 12.41 & 7.55 & 1.75 & 48.04 & 25.45 & 2.64 & 1.00 & 3.68 & 2.65 \\
\hline
\end{tabular}

Tabel 2. presents information on the degree of correlation between GDP, URBAN, FERTY and UNEMPLOY used in multivariate regression analysis. Matrix shows that in general the correlation between the independent variables is not strong multicolinearity problems occur.
TABLE II.

CORRELATION MATRIX FOR THE EXPLANATORY VARIABLES

\begin{tabular}{|l|c|c|c|c|}
\hline & GDP & UNEMPLY & URBAN & FERTY \\
\hline GDP & 1.000000 & 0.056613 & 0.764574 & -0.504872 \\
\hline UNEMPLY & 0.056613 & 1.000000 & 0.229688 & 0.146851 \\
\hline URBAN & 0.764574 & 0.229688 & 1.000000 & -0.522999 \\
\hline FERTY & -0.504872 & 0.146851 & -0.522999 & 1.000000 \\
\hline
\end{tabular}


The results of the study as shown in Table III indicate that the relationship between economic development and female labor force participation follows the $U$ pattern. This means that for the ASEAN region during 21 years it supports $U$ hypothesis. This result supports previous research by [6], [11] [12] [13] ] and [14]. This condition indicates that the level of participation of female labor force in the ASEAN region as a whole during the early period of development will decrease due to the effect of industrialization although it will again increase in relative amount of service sector. Particularly in the manufacturing sector, the hypothesis $U$ points to the withdrawal of manpower in large numbers thus increasing the availability of employment which will attract the participation rate of the female labor force.

For control variables, the impact of urban population on female labor force participation is negative and significant. The negative sign shows the higher the proportion of the population living in urban areas, the higher the participation of the female labor force. These results are consistent with the expectations and studies [6], [11] and [16] who found significant negative urban population influences on the ladder of labor force participation.

TABLE 3.

ESTIMATIONS RESULTS OF PANEL REGRESSION

\begin{tabular}{|c|c|c|c|c|c|c|}
\hline \multirow[b]{2}{*}{ Explanatory Variables } & \multicolumn{3}{|c|}{ (1) } & \multicolumn{3}{|c|}{ (2) } \\
\hline & Pooled OLS & Fixed Effects & $\begin{array}{c}\text { Random } \\
\text { Effects }\end{array}$ & Pooled OLS & Fixed Effects & $\begin{array}{l}\text { Random } \\
\text { Effects }\end{array}$ \\
\hline Constant & $90.58642 * * *$ & $66.08179 * * *$ & $65.91090 * * *$ & $125.0897 * * *$ & $75.10987 * * *$ & $80.34715 * * *$ \\
\hline GDP & -4.181964 & $-1.819902 * *$ & $-1.724429 * *$ & $-12.34038 * * *$ & $-2.332868 * * *$ & $-2.554047 * * *$ \\
\hline GDP2 & 0.024645 & $0.135653 * *$ & $0.126495^{*}$ & $0.870234 * * *$ & $0.173143 * * *$ & $0.186794 * * *$ \\
\hline URBAN & & & & -0.384152 & $-0.118572 * * *$ & $-0.188819 * * *$ \\
\hline FERTY & & & & $0.601775 * * *$ & $-0.843329 * * *$ & $-1.177277 * * *$ \\
\hline UNEMPLOY & & & & $-1.853191 * * *$ & 0.140392 & 0.104905 \\
\hline R-squared & 0.288302 & 0.984760 & 0.035316 & 0.755572 & 0.985490 & 0.134385 \\
\hline Adjusted R-squared & 0.280650 & 0.983903 & 0.024943 & 0.748894 & 0.984413 & 0.110735 \\
\hline F-statistic & 37.67348 & 1150.141 & 3.404589 & 113.1374 & 914.3076 & 5.682097 \\
\hline Prob(F-statistic) & 0.000000 & 0.000000 & 0.035304 & 0.000000 & 0.000000 & 0.000068 \\
\hline Chow test statistic & & 0.0000 & & & 0.0000 & \\
\hline Hausman test statistic & & & 1.0000 & & & 0.0000 \\
\hline Number of obs & 189 & 189 & 189 & 189 & 189 & 189 \\
\hline
\end{tabular}

This study finds that unemployment have a significant positive effect on female labor force participation. This means that the increase in unemployment will increase female labor force participation in the ASEAN region. This indicates that women still rely on income derived from their husbands or parents (men) so that when there is economic pressure, women are forced to work.

In addition, based on the results of the analysis found the relationship between fertility with female labor force participation is negative and significant. This indicates that the number of women giving birth increases will decrease the participation rate of female labor force due to the limited time for women to access the labor market and participate in improving family welfare. These results also support the study [12], [17], [11], [15] and [18] fertility have a significant negative effect on the participation rate of the female labor force.

\section{CONCLUSIONS}

Based on the analysis of the impact of economic structure changes on female labor force participation in ASEAN region during 1993-2013, it can be concluded and suggested as follow: Overall, there is a relationship between economic development and female labor force participation following the pattern of $U$ in the region ASEAN within the period of 1993-2012. Therefore, it is necessary to formulate specific policies to overcome non-economic constraints such as culture that can reduce the level of women's participation in the world of work.

\section{REFERENCES}

[1] ILO. (2014). World of Work Report 2014: Developing with Jobs. International Labour Organization: Geneva.

[2] Elborgh-Woytek, Katrin., Newiak, Monique., Kochhar, Kalpana., Fabrizio, Stefania., Kpodar Kangni., Wingender, Philippe., Clements, 
Benedict and Schwartz, Gerd. (2013). Women, Work, and the Economy: Macroeconomic Gains From Gender Equity. IMF Staff Discussion Note

[3] Mincer, J. (1962). Labor Force Participation of Married Women: A Study of Labor Supply in Aspects of Labor Economics. Princeton, N.J.: National Bureau of Economic Research, Princeton University Press.

[4] Goldin, Claudia. (1995). The U-shaped Female Labor Force Function In Economic Development and Economic History, Working Paper Series (Working Paper No. 4707), National Bureau of Economic Research, New York, NY.

[5] Mammen, K., and Paxson, C. (2000). Women's Work and Economic Development. The Journal of Economic Perspectives, 14(4), 141-164.

[6] Tansel, A. (2002). Economic Development and Female Labor Force Participation in Turkey: Time Series Evidence and Cross Province Estimates. ERC Working Papers in Economics 01/05

[7] Elhorst, Paul. (2009). Economic Development, Fertility Decline and Female Labor Force Participation. Scottish Economic Society Conference 2009 and 4th European Workshop on Labor Economics.

[8] Gaddis, Isis., and Klasen, Stephan. (2011). Economic Development, Structural Change and Women's Labor Force Participation: A Reexamination of the Feminization U Hypothesis. Courant Research Centre: Poverty, Equity and Growth - Discussion Papers, No. 71

[9] Lahoti, Rahul. and Swaminathan, Hema. (2013). Economic Growth and Female Labour Force Participation in India. Indian institute of Managemen Bangalore. Working Paper No: 414.

[10] Lechman, Ewa. and Okonowicz, Anna. (2013). Are Women Important For Economic Development? An Evidence on Women'S Participation in Labor MarketaAnd Their Contribution to Economic Growth in 83 World Countries. GUT Faculty of Management and Economics. Working Paper Series A (Economics, Management, Statistics) No 13/2013 (13).
[11] Tsani, Stella., Paroussos, Leonidas., Fragiadakis, Costas., Charalambidis. Ioannis., and Capros, Pantelis. (2012). Female Labour Force Participation and Economic Development in Southern Mediterranean Countries: What scenarios for 2030?. MEDPRO Technical Report No. 19/December 2012

[12] Bloom, David E., Canning, David., Fink, Günther., and Finlay, Jocelyn E. (2009). Fertility, Female Labor Force Participation, and The Demographic Dividend. Journal Econ Growth. 14:79-101

[13] Çakır, Onur. (2009). The Relationship between Economic Development and Female Labor Force Participation within the Framework of UShaped Hypothesis: Evidence from Turkey. Master Tesis. Schoo; of Economics and Managemen Lund University

[14] Baah-Boateng, William., Nketiah-Amponsah. Edward, and Frempong, Richard. (2013). The Effect of Fertility and Education on Female Labourforce Participation in Ghana. Ghanaian Journal of Economics, Vol. 1: 119-137

[15] Aboohamidi, Abbas and Chidmi, Benaissa. (2013). Female Labor Force Participation in Pakistan and Some MENA Countries. Southern Agricultural Economics Association Annual Meeting 2013

[16] Özerkek, Yasemin. (2013). Unemployment and Labor Force Participation: A Panel Cointegration Analysis for European Countries. Applied Econometrics and International Development Vol. 13-1.

[17] Chaudhuri., Sanjukta. (2010). Women's Empowerment in South Asia and Southeast Asia: A Comparative Analysis. MPRA Paper No. 19686.

[18] Hanafiah, Hazlenah. and Jemain, Abdul Aziz. (2013). Impact of Women Participation in Economic Development on Fertility in Peninsular Malaysia. 4th International Conference on Business and Economic Research (4th ICBER 2013) Proceeding. 